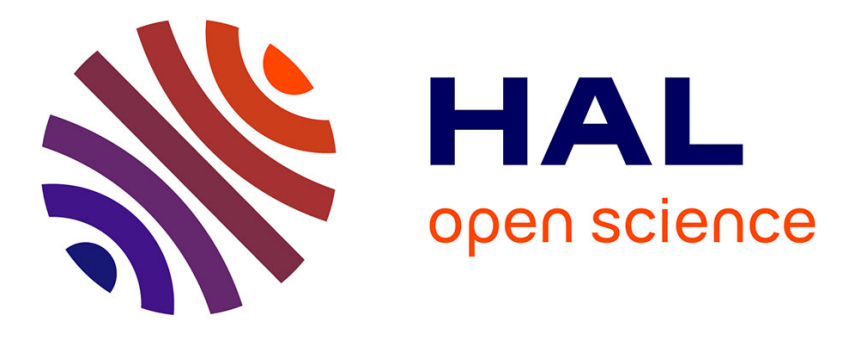

\title{
Preliminary study of CO 2 variations at Amsterdam Island (Territoire des Terres Australes et Antarctiques Francaises)
}

\author{
A. Gaudry, J. M Ascencio, G. Lambert
}

\section{- To cite this version:}

A. Gaudry, J. M Ascencio, G. Lambert. Preliminary study of CO 2 variations at Amsterdam Island (Territoire des Terres Australes et Antarctiques Francaises). Journal of Geophysical Research, 1983, 88 (C2), pp.1323. 10.1029/JC088iC02p01323 . hal-03514043

\section{HAL Id: hal-03514043 \\ https://hal.science/hal-03514043}

Submitted on 6 Jan 2022

HAL is a multi-disciplinary open access archive for the deposit and dissemination of scientific research documents, whether they are published or not. The documents may come from teaching and research institutions in France or abroad, or from public or private research centers.
L'archive ouverte pluridisciplinaire $\mathbf{H A L}$, est destinée au dépôt et à la diffusion de documents scientifiques de niveau recherche, publiés ou non, émanant des établissements d'enseignement et de recherche français ou étrangers, des laboratoires publics ou privés. 


\title{
Preliminary Study of $\mathrm{CO}_{2}$ Variations at Amsterdam Island (Territoire des Terres Australes et Antarctiques Francaises)
}

\author{
A. Gaudry, ${ }^{1}$ J. M. Ascencio, and G. Lambert ${ }^{2}$ \\ Centre des Faibles Radioactivités, Centre National de Recherches Scientifiques \\ 91190 Gif sur Yvette, France
}

\begin{abstract}
The preliminary measurements of atmospheric $\mathrm{CO}_{2}$ concentrations performed at Amsterdam Island between April and the end of 1980 showed two kinds of short-term variations. The first one, attributed to local effects of the photosynthesis of the island vegetation, does not seem considerably to affect the monthly mean $\mathrm{CO}_{2}$ concentrations. The second one has been attributed to long range transport phenomena. That corresponds to large scale meteorological perturbations and generally is correlated with variations of the atmospheric radon concentrations. Therefore, the existence of regional $\mathrm{CO}_{2}$ sources and sinks in the southern hemisphere can be felt at a very large distance. Consequently, isolated measurements of geographical gradients, could correspond to a transitory situation and should not be utilized for the determination of these sources and sinks.
\end{abstract}

\section{INTRODUCTION}

It is well known that the atmospheric $\mathrm{CO}_{2}$ increase recorded by Keeling et al. [1976a,b], is accounted for by only $50 \%$ of the fossil fuel combustion [Broecker et al., 1979]. The missing amount has certainly been absorbed by the other reservoirs. Therefore, the future change in $\mathrm{CO}_{2}$ concentrations is highly dominated by the carbon exchanges between the atmosphere and those main reservoirs: continental biomass and seawater. A good knowledge of these exchanges should imply to sight the main sources and sinks of atmospheric $\mathrm{CO}_{2}$.

One possible strategy consists in the determination of the geographical gradients of the atmospheric concentration and of their seasonal changes [C. D. Keeling, unpublished manuscript, 1981; Fraser et al., 1983]. It has been shown by Komhyr and Machta [1981], that in the southern hemisphere the average differences of concentration, between polar and tropical latitudes could be of the order of $2 \mathrm{ppm}$ or even less. Consequently, the accuracy required for $\mathrm{CO}_{2}$ monitoring should be as close as possible to $0.1 \mathrm{ppm}$. Such an accuracy requires in addition to solving problems of metrology and standardization, avoiding any interference due to local effects. Now it has been shown at several stations that the $\mathrm{CO}_{2}$ concentration variations reach sometimes more than ten ppm, under the influence of local sources or sinks [Lowe et al., 1979], from human or vegetal origin, [Lowe et al., 1979], as well as from the volcanic activity [Miller et al., 1978]. For this reason, we have selected the Amsterdam Island, to establish, in that part of the southern hemisphere, a station for the study of the background pollution, as free as possible from local perturbations.

\section{The Amsterdam Island Station}

Amsterdam Island (Territoire des Terres Australes et Antarctiques Francaises) is located in the South Indian Ocean (Figure 1: $37^{\circ} 47^{\prime} \mathrm{S}, 77^{\circ} 31^{\prime} \mathrm{E}$ ) respectively 3.400 and $5.000 \mathrm{~km}$ off Madagascar and South Africa, which are the nearest continents to be considered in these latitudes to leeward of westerly winds.

There is no active volcanism and no regular marine or air traffic corridors in the vicinity of the island. The population is

\footnotetext{
I Also at ORSTOM/TAAF, Paris, France.

2 Also at Université de Picardie, Saint Quentin, France.

Copyright 1983 by the American Geophysical Union.
}

Paper number $2 \mathrm{C} 0880$. 0148-0227/83/002C-0880\$05.00 limited to about 30 people, living at the scientific base Martin de Viviès (Figure 2a).

The flora has been described by $H$. Schenk [1904]. A limited number of species predominate, defining approximately three different areas as it can be seen in Figure $2 b$. The scarce specimen (less than one hundred), of Phylica Nitida, a low tree, specific of Amsterdam and Tristan Da Cunha Islands, are confined in the eastern part, within a one hectare-area. The surroundings of the sampling point at Pointe Bénédicte, $2.5 \mathrm{~km}$ westwards from Martin de Viviès, are mainly composed of graminea.

Carbon dioxide has been monitored there since April 1980. Meteorological records [Annales de la Météorologie, 1977] show that the wind is blowing $60 \%$ of the time directly from the sea (Figure $2 c$ ), i.e., from the $260^{\circ}$ to $60^{\circ}$ sector.

Therefore, this site looks particularly well adapted to a background $\mathrm{CO}_{2}$ monitoring station.

\section{Experimental Procedures}

The air is collected on the top of an 8-m high aluminium tower, set up at several tens of meters of a cliff (Figure 3). The flow rate is $0.251 \mathrm{~min}^{-1}$. The air sampled crosses successively (1) a membrane pump Hartmann-Braun WISA 2, located in the

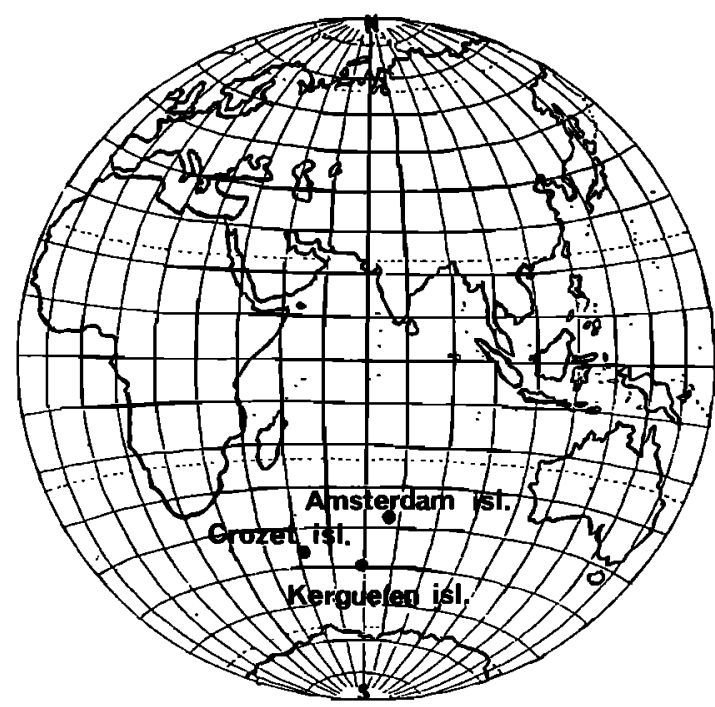

Fig. 1. The French islands in the subantarctic areas. 


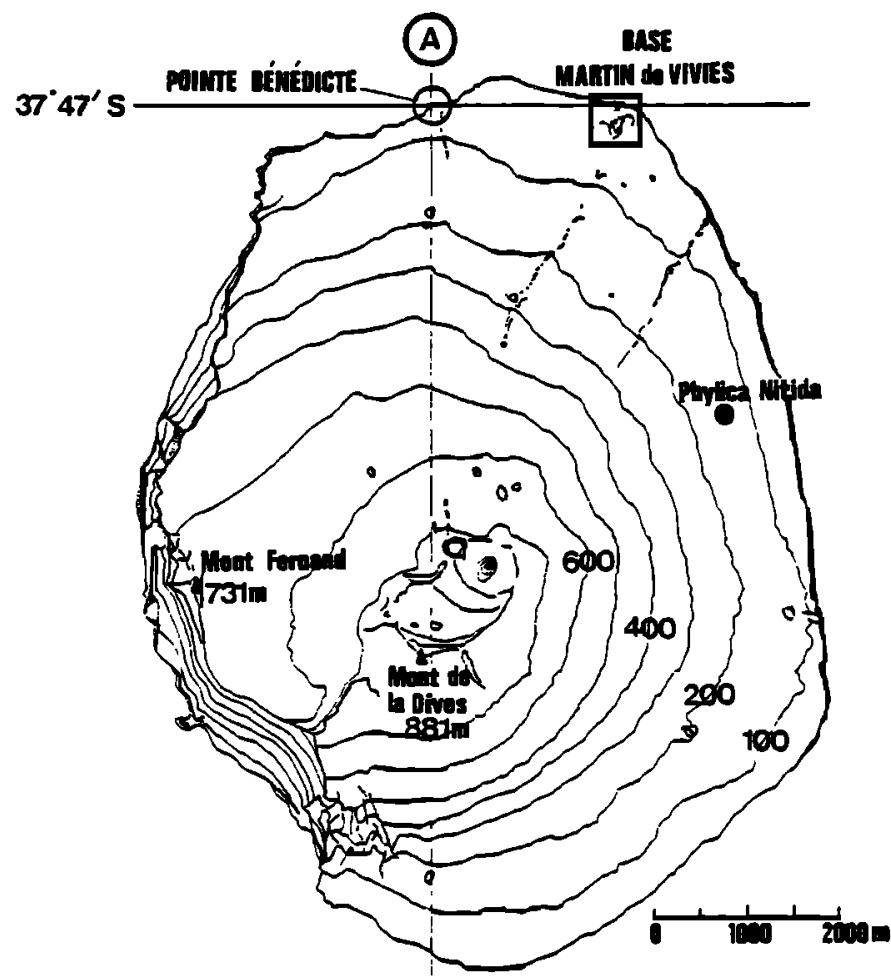

(B)

$\pi T^{\prime} E$

FIG 2A

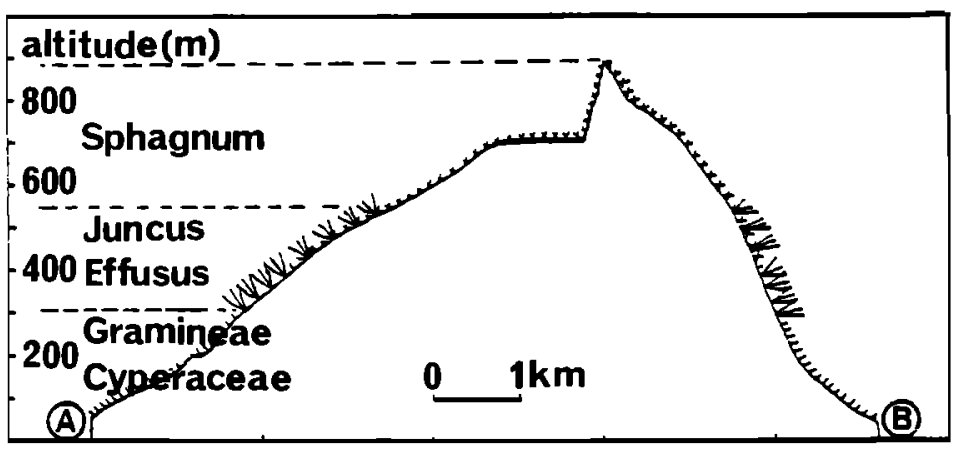

FIG 2B

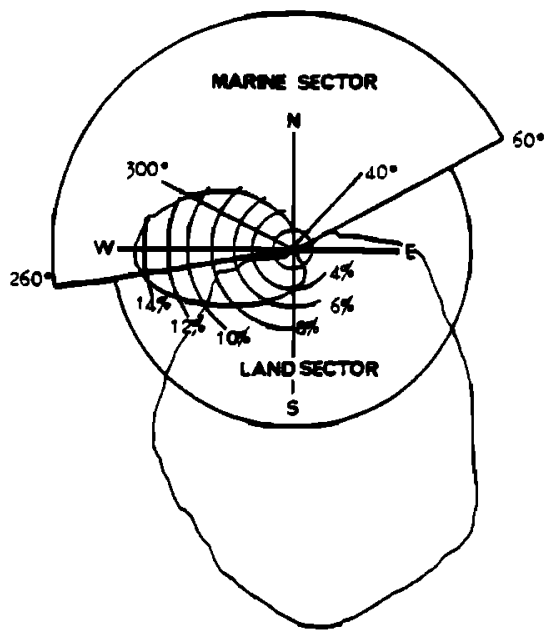

FIG 2C

Fig. 2. (a) Map of Amsterdam Island with the contour-lines. In the eastern part, a black point denotes the location of a few trees 'Phylica Nitida,' a Rhamnaceae growing in the island. (b) Altitude profile, following the north-south AB section, showing the main vegetal species with respect to the elevation. (c) Wind rose corresponding to the meteorological data recorded between 1951 and 1971.

building 1 (Figure $3 b$ ), (2) a $-55^{\circ} \mathrm{C}$ cold trap that removes water vapor (Figure 3c), and (3) a $22-\mathrm{m}$ long aluminium pipe with a 6-mm inner diameter.

Every hour, two field standard gases at 320 and $345 \mathrm{ppm}$ in $\mathrm{N}_{2}$, respectively, are introduced during $5 \mathrm{~min}$ each, into the analyzer. Every other week, both are compared with another pair of standard gases whose pressure remains approximately constant.

During the first year of measurements, no standard gas certified by the Scripps Institution of Oceanography was available at Amsterdam Island. Consequently, the whole of the following results are expressed in an arbitrary scale.

\section{VARIABILITY AND LOCAL EFFECT}

Two different shapes of records have been obtained and are shown in Figure 4. The first kind consists in a very steady curve and corresponds to either winds blowing from the marine sector and faster than $3 \mathrm{~m} \mathrm{~s}^{-1}$, or strong winds faster than $10 \mathrm{~m}$ $s^{-1}$. The second kind, obtained in weak winds, for which the direction was not well defined, or for air masses having rather 

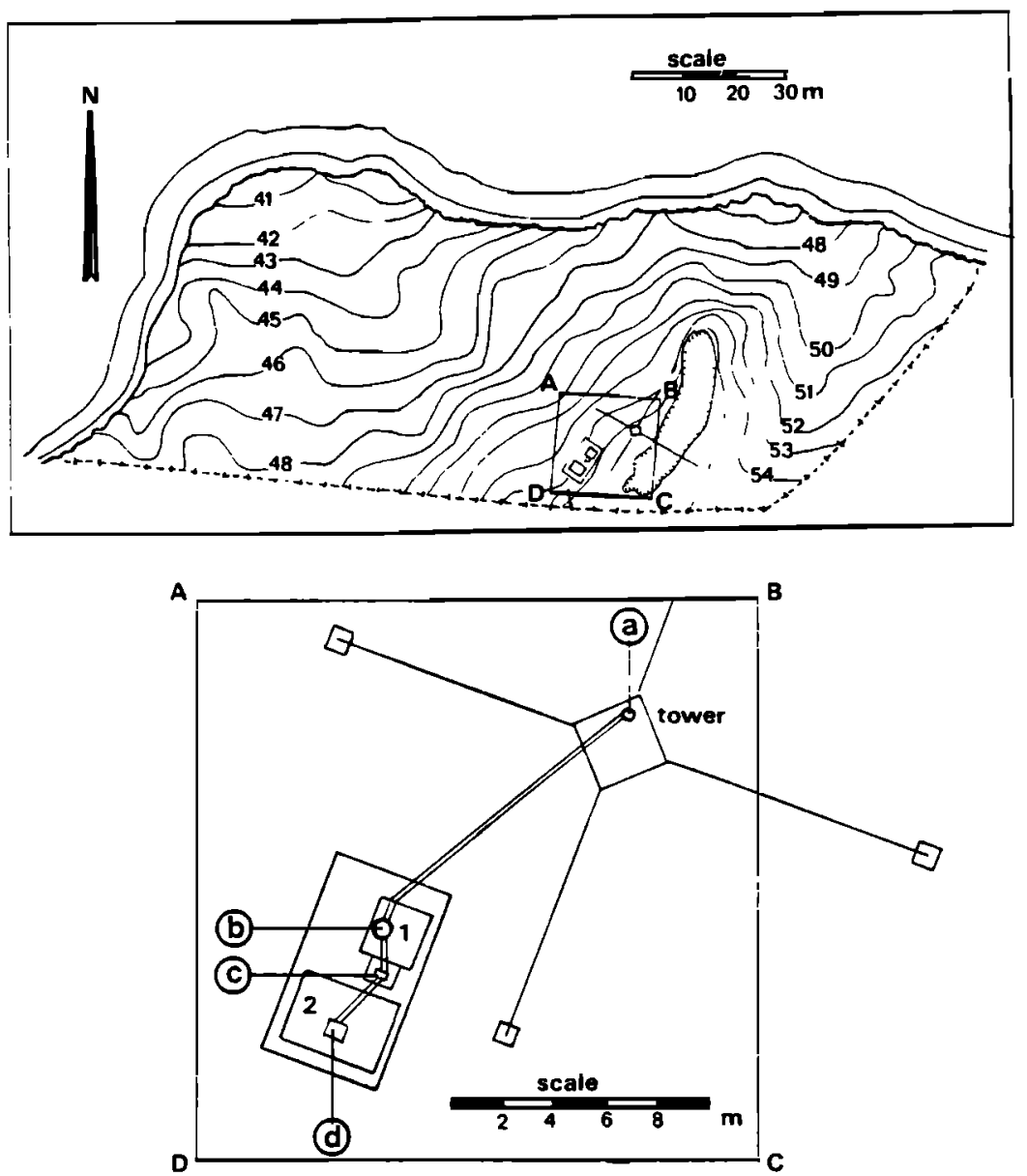

Fig. 3. At the top: The site of the sampling point at Pointe Bénédicte. The particular square ABCD has been enlarged at the bottom to show the implantation of the substructure: (a) sampling point at the top of the 8-m high tower; (b) building 1 : electrical supplies and pumps; (c) ventilated box with the cold trap; $(d)$ analyzer building (2).

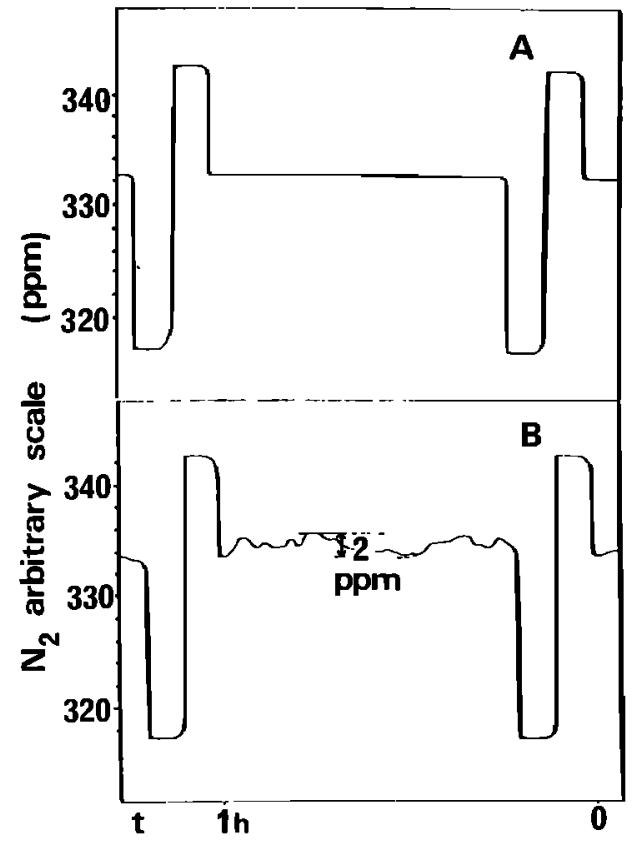

Fig. 4. One-hour records of atmospheric $\mathrm{CO}_{2}$ concentrations obtained at Amsterdam Island. (a) In 1980, October 21, 14 hours, by a 13 $\mathrm{m} \mathrm{s}^{-1}$ wind from the $300^{\circ}$ direction. (b) In 1980 , October 22,4 hours by 1 to $2 \mathrm{~m} \mathrm{~s}^{-1}$ winds from the $100^{\circ}$ (standard deviation $\sigma=0.78$ ). slowly crossed over the island, presents significant fluctuations.

A short-term variability can be estimated by means of the hourly standard deviation $(\sigma)$ calculated from 10 points taken every $5 \mathrm{~min}$. It has been observed that for a wind sector comprised between $300^{\circ}$ and $040^{\circ}$ (see Figure $2 c$ ), $\sigma$ is frequently less than $0.2 \mathrm{ppm}$.

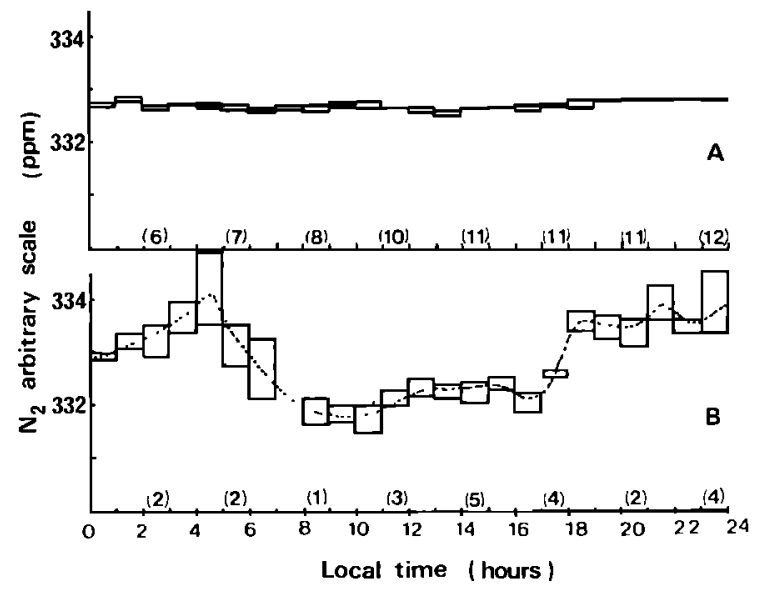

Fig. 5. One-day evolutions of atmospheric $\mathrm{CO}_{2}$ concentration at Amsterdam Island, in 1980, $(a)$ in September 19 by marine sector $\left(300^{\circ}-320^{\circ}\right)$ and $(b)$ in October 22 by land sector $\left(160^{\circ}-260^{\circ}\right)$. 

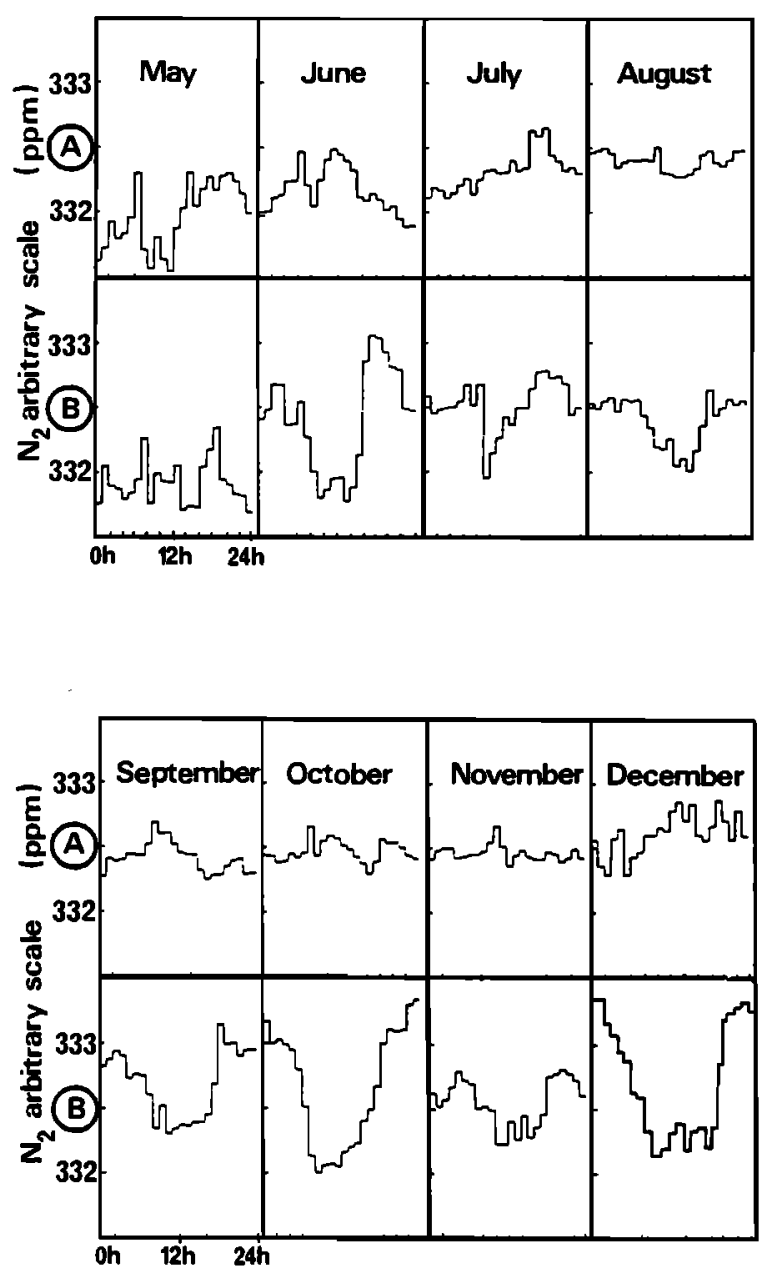

Fig. 6. Average daily atmospheric $\mathrm{CO}_{2}$ variation from the marine sector $\left(300^{\circ}-040^{\circ}\right)$ and from the land sector $\left(60^{\circ}-260^{\circ}\right)$.

On the contrary, in air from a by-land sector $\left(060^{\circ}\right.$ to $\left.260^{\circ}\right)$, a possible influence of the soil and of the vegetation of the island is indicated by $\sigma$ reaching $1.75 \mathrm{ppm}$.

\section{DiURnal Variations}

In agreement with the preceding remarks, it can be observed that, as far as marine air masses are concerned, no diurnal variation of $\mathrm{CO}_{2}$ concentration occurs (see Figure 5a). In contrast, by land sector winds, a minimum of the $\mathrm{CO}_{2}$ con-

TABLE 1. $\mathrm{CO}_{2}$ Mean Monthly Values

\begin{tabular}{|c|c|c|c|}
\hline Month & $\begin{array}{c}(1) \\
\text { Monthly Mean } \\
\mathrm{CO}_{2} \text { Content } \\
\text { by Marine } \\
\text { Sector, }{ }^{*} \text { ppm }\end{array}$ & $\begin{array}{c}\text { Monthly Mean } \\
\mathrm{CO}_{2} \text { Content } \\
\text { by Land } \\
\text { Sector, } \dagger \text { ppm }\end{array}$ & $\begin{array}{c}\text { Difference } \\
\text { Between } \\
\text { sectors }\end{array}$ \\
\hline May & 331.98 & 331.91 & -0.07 \\
\hline June & 332.19 & 332.42 & +0.23 \\
\hline July & 332.35 & 332.54 & +0.19 \\
\hline August & 332.40 & 332.42 & +0.02 \\
\hline September & 332.41 & 332.69 & +0.28 \\
\hline October & 332.47 & 332.67 & +0.20 \\
\hline November & 332.46 & 332.55 & +0.09 \\
\hline \multirow[t]{2}{*}{ December } & 332.63 & 332.66 & +0.03 \\
\hline & & Av & ge: $\overline{0.12}$ \\
\hline
\end{tabular}

*The marine sector corresponds to a wind blowing from the sector $300^{\circ}-040^{\circ}$

tThe land sector corresponds to a wind blowing from the sector $060^{\circ}-260^{\circ}$ (see text and figure 2 ).

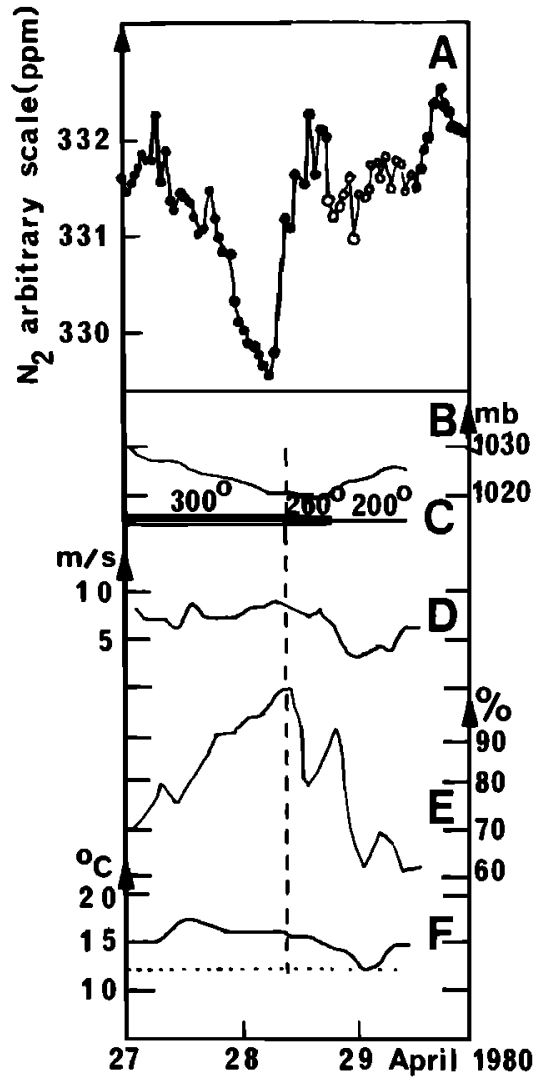

Fig. 7. Observation of a $2.5 \mathrm{ppm}$ decrease of $\mathrm{CO}_{2}$ concentration (a), corresponding to the passage of a meteorological perturbation observed at Amsterdam Island. Curve (b) represents the barometric pressure, $(c)$ the wind direction, $(d)$ the wind velocity, $(e)$ the relative humidity, and $(f)$ the air temperature.

centration can be observed at the middle of the day (see Figure $5 b$ ), which could be attributed to the photosynthesis of the island vegetation.

In order to quantify this local effect, we have calculated for every month, an average daily variation for both wind sectors.

In Figure 6, the mean $\mathrm{CO}_{2}$ concentrations, corresponding to the marine wind sector, do not present any clear diurnal trend: the amplitude of the mean daily variations is less than 0.76 ppm. By land sector (Figure 6), a clear diurnal effect can be observed, with a magnitude ranging from $0.58 \mathrm{ppm}$ to 1.34 ppm. However, this effect does not seem to be related to the seasons, but rather to the specific character of the local land biomass, as well as meteorology.

It is worthwhile pointing out that the mean monthly values obtained for both sectors, are very close, as is apparent in Table 1.

\section{LONG-Range Transport of $\mathrm{CO}_{2}$ Variations}

As shown above, it has been possible to select meteorological conditions for which any local interference can be ruled out, i.e., winds stronger than $3 \mathrm{~m} \mathrm{~s}^{-1}$ blowing from a $260^{\circ}-60^{\circ}$ sector. However, even in these conditions, a significant $\mathrm{CO}_{2}$ variability is still observed, which can be related to changes in the meteorological parameters (Figure 7).

During the short period between April 20 and September 30, 1980, not less than 29 meteorological fronts of air masses were registered at Amsterdam Island. They are listed in Table 2. In 8 of these 29 , the $\mathrm{CO}_{2}$ variations do not stand out from the noise. However, in the other 21 cases the large scale meteorological 
perturbations are associated with significant $\mathrm{CO}_{2}$ variations, also listed in Table 2, with their plus or minus sign amplitudes (in ppm).

A correct interpretation of the phenomenon could be made easier by a correlative study of the atmospheric ${ }^{222} \mathbf{R n}$ concentration. Indeed, this radioactive gas is known to be a good tracer of continental air masses and has been extensively used at the French Subantarctic stations by Lambert et al. [1970, 1972] and Polian [1982]. These authors have particularly shown that significant increases of ${ }^{222} \mathrm{Rn}$ concentration are stabily associated with meteorological fronts, during several days, and can be observed successively at Crozet, Kerguelen, and Amsterdam islands. The positions of these islands are shown in Figure 1. Hence, the existence of significant peaks of ${ }^{222} \mathrm{Rn}$, that is ${ }^{222} \mathrm{Rn}$ concentrations larger than 1.5 picocuries $\mathrm{m}^{-3}$, is mentioned in Table 2 .

Two typical examples of the progression of a radon event from west to east are given in Figures 8 and 9, where the $\mathrm{CO}_{2}$ concentration at Amsterdam Island is also indicated. A clear correlation between $\mathrm{CO}_{2}$ and ${ }^{222} \mathrm{Rn}$ concentrations can be seen in these figures. However, this correlation seems to be sometimes positive and sometimes negative.

The results gathered in Table 2 can be summarized as follows: out of over 29 meteorological fronts, 5 are neither accompanied with a radon event, nor a $\mathrm{CO}_{2}$ event, 7 are correlated simultaneously with a radon peak higher than $4 \mathrm{pci} \mathrm{m}^{-3}$, and with a $\mathrm{CO}_{2}$ concentration increase, 14 are correlated with a $\mathrm{CO}_{2}$ concentration decrease, 8 of these events being accompanied with a small, but significant radon peak, and 3 correspond

TABLE 2. Correlative Variations of $\mathrm{CO}_{2}$ and ${ }^{222} \mathrm{Rn}$ Concentrations With the Passage of Meteorological Fronts Registered at Amsterdam Island

\begin{tabular}{lcc}
\hline \multicolumn{1}{c}{ Date } & $\begin{array}{c}\mathrm{CO}_{2} \text { Event } \\
\text { Amplitude in ppm }\end{array}$ & $\begin{array}{c}{ }^{222} \text { Rn Event, } \\
\text { picocuries } / \mathbf{m}^{3}\end{array}$ \\
\hline April 20, 1980 & -0.8 & 0 \\
April 24, 1980 & -2 & 0 \\
April 27-28, 1980 & -2.5 & 0 \\
May 12, 1980 & 0 & 1.8 \\
June 2, 1980 & +0.7 & 4 \\
June 6-9, 1980 & -0.8 & 1.6 \\
June 13, 1980 & 0 & 0 \\
June 15-17, 1980 & +1.3 & 4 \\
June 20, 1980 & -1.3 & 0 \\
July 1-2, 1980 & -0.7 & 1.6 \\
July 4-5, 1980 & -1.3 & 0 \\
July 8, 1980 & 0 & 0 \\
July 10-11, 1980 & 0 & 0 \\
July 12, 1980 & 0 & 0 \\
July 18, 1980 & 0 & 2 \\
July 25-27, 1980 & +0.65 & 4.5 \\
July 29-31, 1980 & +0.7 & 8.5 \\
Aug. 2-3, 1980 & 0 & 0 \\
Aug. 4-5, 1980 & +0.5 & 5 \\
Aug. 12-13, 1980 & +0.9 & 6.5 \\
Aug. 17-18, 1980 & +0.85 & 4 \\
Aug. 21-23, 1980 & -1.1 & 1.6 \\
Aug. 25-26, 1980 & -0.6 & 1.9 \\
Aug. 29-31, 1980 & 0 & 2 \\
Sept. 2-3, 1980 & -1.1 & 2.5 \\
Sept. 7-8, 1980 & -0.7 & 1.5 \\
Sept. 15-16, 1980 & -1 & 0 \\
Sept. 17-21, 1980 & -1.6 & 1.6 \\
Sept. 23-26, 1980 & -1.1 & \\
\hline & & 2 \\
\hline
\end{tabular}

The plus and minus signs correspond to $\mathrm{CO}_{2}$ concentration increases and decreasès, respectively, compared with the background. The radon background between 0 and $1.5 \mathrm{pCi} / \mathrm{m}^{3}$, is indicated by 0 .

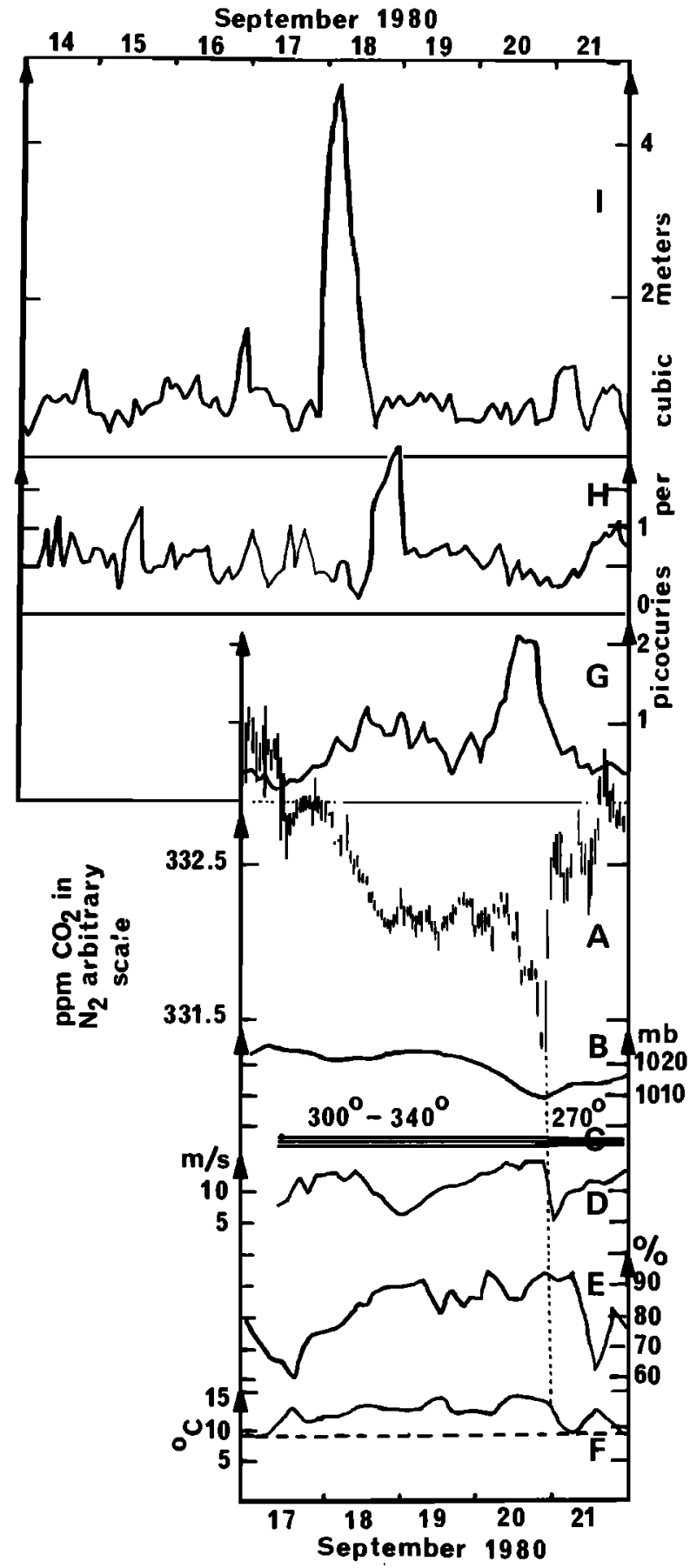

Fig. 8. Negative correlation between ${ }^{222} \mathrm{Rn}(\mathrm{G})$ and $\mathrm{CO}_{2}$ concentrations ( \pm hourly mean standard deviation) (a) at Amsterdam Island, obtained during the passage of a front in 1980, between September 17 and 21 . Curve $(b)$ represents the barometric pressure, $(c)$ the wind direction, $(d)$ the wind velocity, $(e)$ the relative humidity, and $(f)$ the air temperature. The radon events are observed at Kerguelen $(\mathrm{H})$ and Crozet (I) islands with respective lapse times of 36 and 56 hours before the corresponding passage at Amsterdam Island.

to a small peak of radon, without a significant $\mathrm{CO}_{2}$ concentration variation.

The existence of peaks of radon concentration has been interpreted as an advection of air from South Africa. Therefore, it seems very likely that the $\mathrm{CO}_{2}$ variations should have the same origin.

It is well known that, owing to the low vertical eddy diffusion of the air during the night, the radon concentration over a 


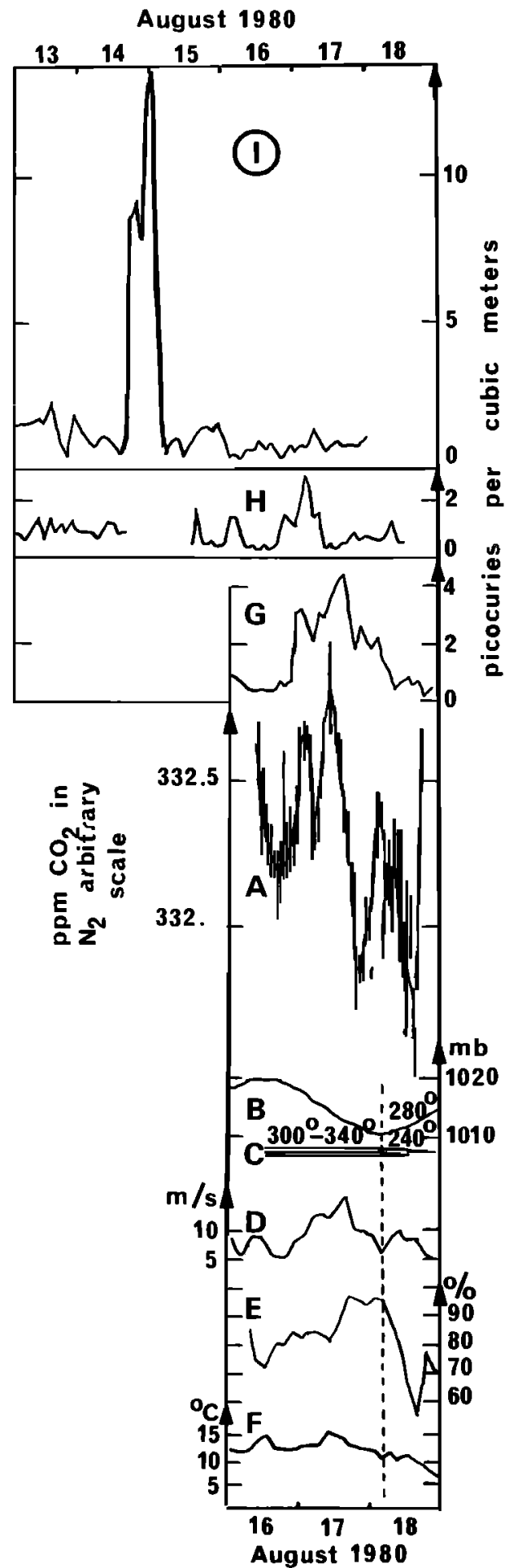

Fig. 9. Positive correlation between ${ }^{222} \mathrm{Rn}$ (G) and $\mathrm{CO}_{2}$ concentrations- $( \pm$ hourly mean standard deviation) (a) at Amsterdam Island, obtained during the passage of a front between August 16 and 18,1980 . Curve $(b)$ represents the barometric pressure, $(c)$ the wind rotations, $(d)$ the wind velocity, $(e)$ the relative hymidity, and $(f)$ the air temperature. The radon events are observed at Kerguelen (H), Crozet (I) islands, with respective lapse-times at 12 and 60 hours with the corresponding passage at Amsterdam Island.

continental area is then higher than during the day. The same diurnal variation is also observed in the case of $\mathrm{CO}_{2}$ and is attributed to photosynthesis. This similitude has been shown by Dörr et al. [1981], who found in Europa, a good correlation between ${ }^{222} \mathrm{Rn}$ and $\mathrm{CO}_{2}$ concentrations with a diurnal pattern.

Actually, it can be observed in Table 2, that all ${ }^{222} \mathrm{Rn}$ peaks, reaching or exceeding 4 pci $\mathrm{m}^{-3}$ are correlated with $\mathrm{CO}_{2}$ concentration increases. Conversely, the $\mathrm{CO}_{2}$ concentration decreases are systematically obtained when the ${ }^{222} \mathbf{R n}$ concentrations are smaller than $2.5 \mathrm{pci} \mathrm{m}^{-3}$ or even at its background level.

To summarize, it seems that we can observe at Amsterdam Island, with similar frequencies, three different kinds of nonlocal variations of the atmospheric $\mathrm{CO}_{2}$ concentration, of the order of $\pm 1 \mathrm{ppm}$ :

1. $\mathrm{CO}_{2}$ concentration increases associated with ${ }^{222} \mathrm{Rn}$ peaks superior or equal to $4 \mathrm{pci} \mathrm{m}^{-3}$, which are interpreted as advections of night air masses from South Africa. In a few cases, the correlation between ${ }^{222} \mathrm{Rn}$ and $\mathrm{CO}_{2}$ concentrations is very sharp, as shown in Figure 10.

2. $\mathrm{CO}_{2}$ concentration decreases associated with small ${ }^{222} \mathrm{Rn}$ peaks between 1.5 and $2.5 \mathrm{pci} \mathrm{m}^{-3}$ interpreted as advections of day air masses from South Africa.

3. $\mathrm{CO}_{2}$ concentration decreases non-associated with any significant ${ }^{222} \mathrm{Rn}$ variation that possibly could be attributed to an absorption process by the sea water.

In the three examples shown in Figures 7,8 , and 9, the evolution of the meteorological parameters shows a simultaneous increase of the temperature and the relative humidity at the start of each $\mathrm{CO}_{2}$ event. This enables us to admit that these air masses have a tropical origin. This tropical character sharply disappears with the passage of the cold front and the end of the $\mathrm{CO}_{2}$ event.

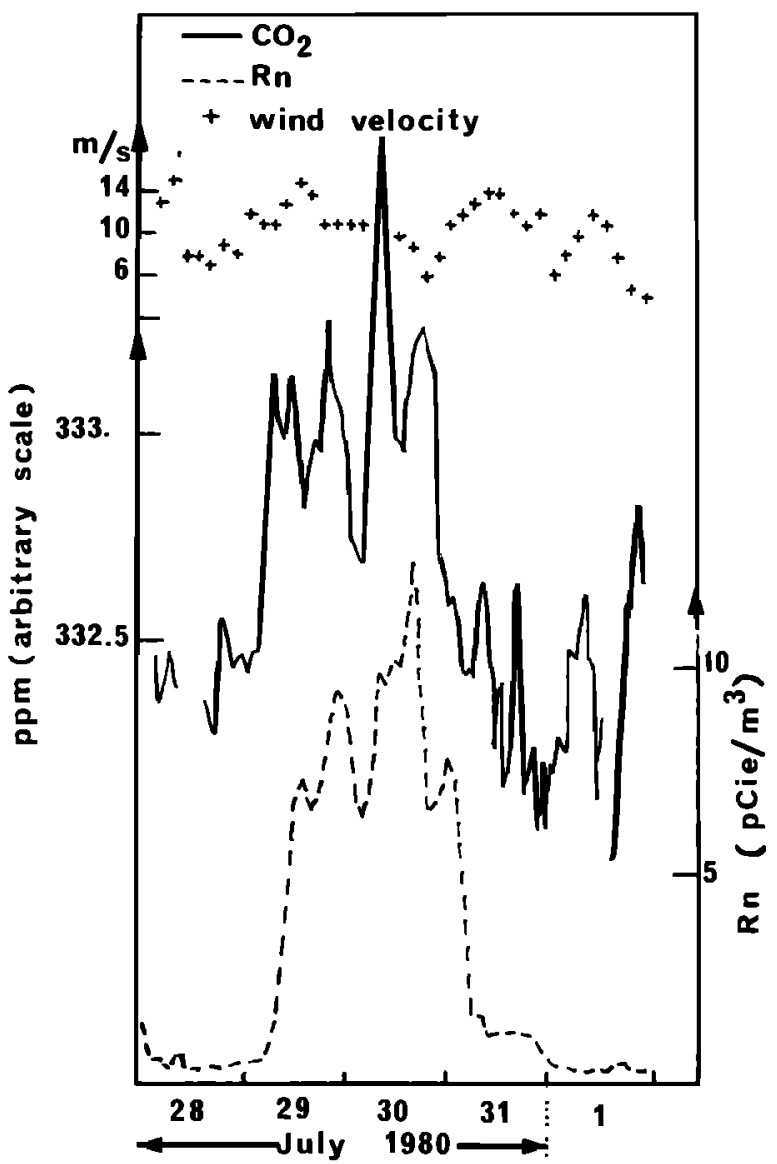

Fig. 10. Variations of $\mathrm{CO}_{2}$ (full line), and ${ }^{222} \mathrm{Rn}$ (dashed-line) concentrations obtained from July 29 to 31, 1980, by strong winds (6 to 14 $\mathrm{m} \mathrm{s}^{-1}$ ) from the marine sector. 


\section{Conclusion}

After a first year of $\mathrm{CO}_{2}$ monitoring, and despite the lack of an intercalibration, some interesting results have been obtained at Amsterdam Island, concerning the existence of a short-term variability.

Despite the exceptionally isolated situation of the sampling site, a first kind of variations can be attributed to local causes. When the winds are very light, or when moderate breezes cross the island, the photosynthetic activity of the vegetal mass generates some diurnal variations of the $\mathrm{CO}_{2}$ concentration of the order of $1 \mathrm{ppm}$, reaching scarcely $1.6 \mathrm{ppm}$. However, a good knowledge of the meteorological conditions, and allowing for the standard deviation, enable us to discard any data disturbed by local interferences. Moreover, we have seen that the mean monthly value is very little affected by such an effect, in the case of Amsterdam Island, where the vegetation is sparse.

On the other hand, it seems that the concentrations of atmospheric trace gases, like ${ }^{222} \mathrm{Rn}$ and $\mathrm{CO}_{2}$ are rather well preserved along trajectories longer than $5000 \mathrm{~km}$.

Therefore, the existence of $\mathrm{CO}_{2}$ regional sources and sinks in the southern hemisphere can be felt at a very large distance. It involves $\mathrm{CO}_{2}$ variations of the order of 0.5 to $2.5 \mathrm{ppm}$ during 1 to 3 days in a remote station. Consequently, the measurements of geographical gradients at a given time could correspond to a transitory situation and therefore should not be utilized for the determination of these sources and sinks. Such a study could only be made in the future by considering the mean values obtained during a long time in settled stations, or possibly after a very careful study of long range transport phenomena.

Acknowledgments. This program has been supported by the Administration of the Territoire des Terres Australes et Antarctiques Françaises, by NATO, the Commission des Communautés Européennes, and the Programme Interdisciplinaire de la Recherche en Matière d'Environnement. We thank G. Polian for useful discussions, B. Ardouin and A. Jegou for their technical assistance, and the staff in charge of the experiment at Amsterdam Island.

\section{REFERENCES}

Annales Météorologiques de la France d'Outre Mer, Fas. 2, Départements et Territoires Français de l'Océan Indien et de l'Antarctique, Office National de Météorologie, 1977.
Broecker, W. S., T. Takahashi, H. J. Simpson, and T. H. Peng, Fate of fossil fuel carbon dioxide and the global carbon budget, Science, 206, 409-418, 1979.

Dörr, H., B. Kromer, I. Levin, K. O. Münnich and H.-J. Volpp, $\mathrm{CO}_{2}$ and Radon 222 as tracers for atmospheric transport, J. Geophys. Res., this issue.

Fraser, P. J., P. Hyson, and G. I. Pearman. The global distribution of atmospheric carbon dioxide, 1 , Aspects of observations and modeling, submitted to $J$. Geophys. Res., 1983.

Keeling, C. D., R. B. Bacastow, A. E. Bainbridge, C. E. Ekdahl, P. R. Guenther, L. S. Waterman, and J. F. S. Chin, Atmospheric carbon dioxide variations at Mauna Loa Observatory, Hawaii, Tellus, 28, 538-551, $1976 a$.

Keeling, C. D., J. A. Adams, Jr., A. Ekdahl, Jr., and P. Guenther, Atmospheric carbon dioxide variations at the South Pole, Tellus, 28 , $552-564,1976 b$

Komhyr, W. D. and L. Machta, Preliminary results and interpretation of the NOAA Flask Programme, paper presented at the WMO/ICSU/UNEP Science Conference on Analysis and Interpretation of Atmospheric $\mathrm{CO}_{2}$ data, Bern, Switzerland, 1981.

Lambert, G., G. Polian, and D. Taupin, Existence of periodicity in randon concentrations and in large scale circulation at lower altitudes between 40 and $70^{\circ} \mathrm{S}, \mathrm{J}$. Geophys. Res., 75, 2341-2345, 1970.

Lambert, G., B. Ardouin, G. Polian, and J. Sanak, Natural radioactivity balance in the atmosphere of the southern hemisphere, in The Natural Radiation Environment II, edited by J. A. S. Adams, W. M. Lowder, and T. F. Gesell, Conf. 720 805-P2, National Technical Information Service, U. S. Dept. of Commerce, Springfield, Va., 1972.

Lowe, D. C., P. R. Guenther, and C. D. Keeling, The concentration of atmospheric carbon dioxide at Baring Head, New Zealand, Tellus, $31,58-67,1979$.

Miller, J. M., and J. F. S. Chin, Short-term disturbances in the carbon dioxide record at Mauna Loa Observatory, Geophys. Res. Lett., 5, 669-671, 1978.

Polian, G., Radioactivité naturelle atmosphérique dans l'hémisphère Sud, Thesis, Université de Paris, 1982.

Schenck, H., Über flora und vegetation von St. Paul und New Amsterdam, Wissenschaftliche Eryebnisse der Deutschen Tiefsee Expedition Valdivia 1898-1899, t.II, 1st serie, 1904.

(Received January 21, 1982; revised March 19, 1982; acceped March 19, 1982.) 